\title{
Mythos
}

MYTHOS

Rivista di Storia delle Religioni

$14 \mid 2020$

Varia

\section{On Greek Intellectuals and the Roman Emperor Cult}

Gli intellettuali greci e il culto romano dell'Imperatore

\section{Kostas Buraselis}

\section{(2) OpenEdition \\ 1 Journals}

\section{Electronic version}

URL: https://journals.openedition.org/mythos/2151

DOI: $10.4000 /$ mythos.2151

ISSN: 2037-7746

\section{Publisher}

Salvatore Sciascia Editore

\section{Electronic reference}

Kostas Buraselis, "On Greek Intellectuals and the Roman Emperor Cult", Mythos [Online], 14 | 2020,

Online since 31 December 2020, connection on 11 October 2021. URL: http://journals.openedition.org/ mythos/2151 ; DOI: https://doi.org/10.4000/mythos.2151

This text was automatically generated on 11 October 2021

Mythos 


\title{
On Greek Intellectuals and the Roman Emperor Cult
}

\author{
Gli intellettuali greci e il culto romano dell'Imperatore
}

Kostas Buraselis

\section{Introduction}

Since Bowersock's still basic study on the relation of Greek intellectuals to the cult of the Roman Emperor in the second century AD (1973) his findings seem to have acquired a standard value, namely that the cult of the Roman Emperor in the texts and the understanding of Greek writers

for a protracted period [practically from the Augustan to the end of the Antonine age] functioned smoothly without embarrassing or compromising anyone. The complacency of the intellectual elite in the matter of divine emperors was ultimately shattered by aberration within the royal house itself ${ }^{1}$

2 Bowersock's interpretation further concluded that a change may be noticed only in the Severan age after the extremely negative examples of Commodus and Elagabalus, which came «to impel a thoughtful man [: Cassius Dio] to abandon the easy acceptance of the cult and to have pushed the old arguments to conclusions hitherto unexpressed $»^{2}$, that is to the outright rejection of the imperial cult as a sensible and acceptable practice in the relations between the Roman emperor and his subjects. Thus a more or less uniform, affirmative or at least neutral attitude of Greek intellectuals to the fact of this cult until the end of the second century AD was reconstructed. Of course, this seemed easily compatible with the general acceptance of imperial reality and even its eulogy in authors of the same period like Aelius Aristides, who regularly worked out a highly idealized picture of the Roman Empire.

Bowersock based his sketch of this development on a careful analysis of relevant testimonies on the Roman imperial cult in Greek authors from the first to the third cent. AD. We shall come back to these texts in the following parts of this study and we shall weigh their contents anew. However, let us begin this fresh approach to the 
problem by an important, I would even say: revealing, piece of evidence, a testimony of Pausanias, which has not been properly considered in this context so far, apart from its marginal mention in Simon Price's monograph on the Roman Imperial Cult in Asia Minor ${ }^{3}$.

\section{II}

4 Pausanias is a not negligible author of the second cent. AD. His extensive report, diachronically useful as a sort of guide-book on the antiquities of Greece, concerned the relation of the Greeks to their past, especially on the occasion and on the basis of his presentation of old Greece and its monuments as he experienced them in his personal travels. The date of this work, on internal evidence, is to be placed at the latest in the period of Marcus Aurelius. The last specific facts during the author's life mentioned in his work were the victories of that emperor over Germans and Sarmatians in $175 \mathrm{AD}$ $(8.43 .6)^{4}$.

5 At many points in his periegetical work Pausanias confronts, with an understandable though often highly accentuated - sense of classical nostalgia, the glories of the Greek past with the often humble remnants of his times. A point of his relevant remarks touches on our present subject. In his part devoted to Arcadia he comes to relate ${ }^{5}$ the local stories circulating in his contemporary Arcadia on Lykaios and his metamorphosis into a wolf. He accepts the veracity of that story as product of an age when people were much nearer the gods, even as their close associates in daily common life ( $\xi \varepsilon$ vol kai

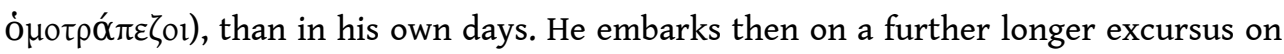
humans who were elevated into divine status in old times, and whose consequent cult has been established ever since. He mentions precise examples of such 'men who became gods', on the basis of their justice and piety: Aristaios, the Cretan Britomartis, and the - more illustrious - cases of Herakles, Amphiaraos, Pollux and Castor. On the other hand, the opposite, negative lifestyle used to be closely observed and evidently punished by the gods in the same period. To express it succinctly, the system of natural deification of morally eminent humans worked soundly during that remote age in Pausanias' eyes. The eventual new gods deserved at that time their generally recognized divinity.

With this pattern of human high merit and corresponding and hallowed elevation Pausanias then contrasts the experience of his age with a concise but eloquent phrase. His different, evidently contemporary experience ( $\left.\dot{\varepsilon} \pi^{\prime} \dot{\varepsilon} \mu \mathrm{ov} \delta \grave{\varepsilon}\right)$ was that the conditions

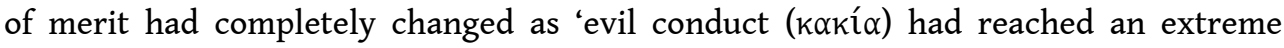
standard all over the earth and its cities'. Thus «no man was any more turned into a

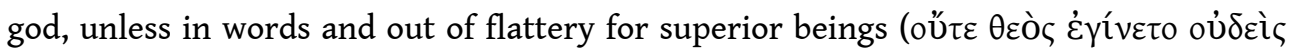

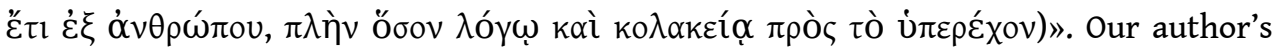
remarks conclude then with bitter realism: «the unjust have encountered divine wrath

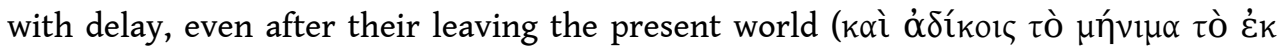

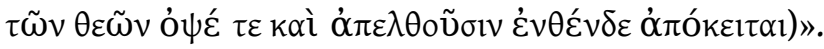

7 The terms used were carefully unspecific but the allusive message is unmistakable. Who could be the superior beings of Pausanias' times celebrated in words and flattery as gods? We can easily understand that it would have been dangerous for Pausanias to

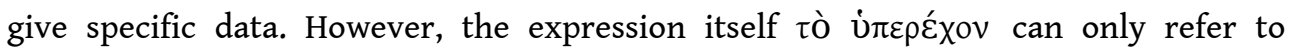


contemporary political rule and its protagonists, which could be nothing else than Rome and the official bearers of its supreme power, that is the emperors.

8 Pausanias' diction itself corroborates this conclusion as one may attest by his comments in another passage ${ }^{6}$ where he relates the honorific statues for Konon and his son Timotheos dedicated by Ionian cities in their sanctuaries after the victory at Knidos (394 BC):

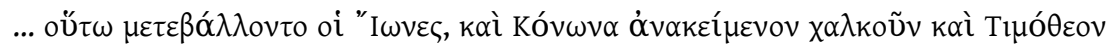

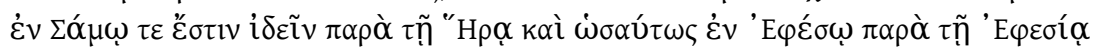

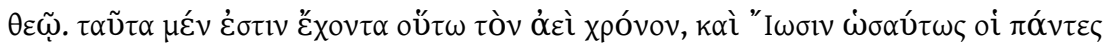

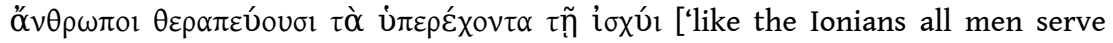
(with a clear connotation of flattering) those excelling in power'] ${ }^{7}$.

In other words, military and the concomitant political power explained those Ionian dedications as typical expressions of human behaviour, obviously resembling the conditions of the Roman Empire. Supremacy justified elevated honours but deification was something more, and Pausanias distanced himself from such a practice in his world with few but clear words.

Thus we do not need to reach the Severan period and Cassius Dio to find a statement of objection to the essence of the imperial cult. Pausanias' verdict was low-voiced but equally und unequivocally negative. The undeserved divinity of rulers in his second century AD world was tantamount to nice words and flattery to superior power, without an inner religious dimension. Those assuming the name of (new) gods owed this only to verbal exaltation and not to genuine value and merit towards people, which would have won them true and permanent recognition as divine beings.

\section{III}

The motif and the significance of verbal flattery as a basic constituent of the imperial cult did not appear here for the first time. We could even speak of a conscious adulatory code of the imperial cult that imposed i. a. the parallelism or equation of imperial with traditional gods and symbols.

It is exactly here that the otherwise 'politically correct' position of Plutarch on the imperial cult becomes relevant. For the wise man of Chaironeia aptly proved his wisdom by his discreetly peripheral allusions to the same subject. In his treatise How to distinguish a flatterer from a friend he commented extensively on flattery as a factor of deterioration for political rulers who rejoiced in being compared with the traditional gods and even assuming their specific attributes. His passage in question ${ }^{8}$ presented examples of rulers in the Greek classical and Hellenistic past, like the tyrants of Syracuse and the Ptolemies, and their unsuitable, that is unworthy, adoption of supposed friends' counsels in connection with the cult of gods and - indirectly themselves. However, his indicative list included also Antonius as a sort of Ptolemaic appendix, and then no inferior person than his imperial majesty Nero, who entered the scene of the theatre and bore the masks and the high shoes of actors after such false friends' advice. Nero's intentional 'divine identity' is then perfectly echoed by Plutarch's final remark in that passage:

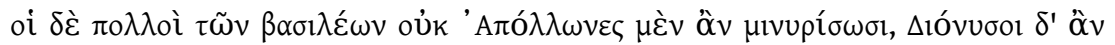

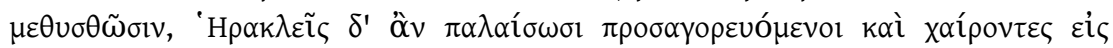

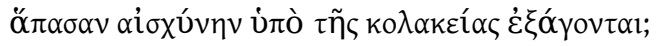


Are not many kings pushed to all sorts of dishonour by their flatterers who call (and thus please them) by the name of Apollo if they sing in a low tone, by that of Dionysus if they get drunk, by that of Herakles if they wrestle?

13 The motif of flattery encouraging to an unworthy assimilation of rulers with divinities is here marked by Plutarch as a frequent, and dishonourable, element of the ruler-cult.

Bowersock did not wish to acknowledge this as an indirect criticism of the imperial cult. He duly pointed out ${ }^{9}$ that «... Nero was not a 'divus', as he had suffered damnatio memoriae, so that Plutarch's mention of his bearing was specific and (Plutarch) a true member of the establishment in denouncing him». However, Plutarch seems to have selected one notorious case while further ones will have been at the same time in his own and his readers' minds: e.g. Caligula or Domitian, similarly obsessed with their divinity and repeatedly celebrated for it. Moreover, the fact of the damnatio memoriae corrected later fame but not the fact of the contemporary misconduct of all those engaged in the divinization of an unworthy ruler. Thus the criticism of excessive flattery drew a deeper and wider net of connections, without promoting its critic to an uncomfortable front. Plutarch was dexterous enough to blame just a peak of divine travesty and let the memory of his readers build up further associations. He was certainly reasonable enough to see the high practical utility of what was already a crucial public institution of the Roman Empire but without concealing or somehow consenting to its excesses. We may be sure that not all 'members of the establishment' in the Empire would have gone so far.

\section{IV}

15 As we already saw in Plutarch's remarks, the flattery of rulers as a primary method of their divine elevation was an old and well-known Hellenistic tool. It is then not a surprise to meet it again adapted to the realities of the Roman imperial cult or to grant the new cult sometimes a special flair for erudition and inventiveness. For the effort is natural to use an appealing intellectual construct to mould and strengthen a religious element partly present and partly sought after, in a discreet but no less efficient way. A case-in-point, also not thoroughly exploited in this context so far, may bring us back to the beginnings of the Empire. Let us see how Krinagoras of Mytilene handled the subject of Augustus' divinity.

Krinagoras was a Mytilenean poet of Augustus' times ${ }^{10}$, who must have joined one or more embassies of his homecity to Augustus in order to attain some crucial privileges for it. Mytilene had managed to be on the loser's side on all civil wars ending the Republic, and diplomatic mobilization to mend relations with Rome was imperative. Even meeting Augustus was on the other hand no easy task, and thus Krinagoras seems to have traveled as far as Spain to fulfill his duty. However, he knew how to appease the new ruler of the Mediterranean world with his art, without becoming cheap in his praise.

17 One of Krinagoras' elegiac poems ${ }^{11}$ describes the original action of a parrot. The bird

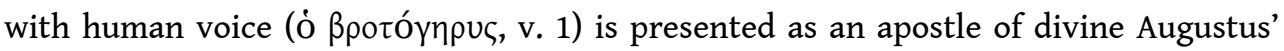
fame in the natural world: having learnt to repeat the phrase Ave (X๙ĩ $\rho$ ) Caesar (v. 6), it had escaped from his cage and flown away to the mountains where he acted as a teacher of that phrase to other birds. Thus the message of salutation to the new god

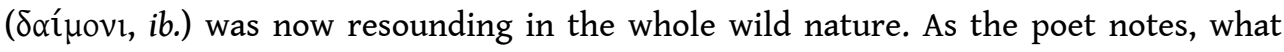


Orpheus had once achieved, that is, to tame all wild animals by his song, was now repeated in a way by that feathery preacher of Augustan divinity. The image is grotesquely superb, one could almost call it the distinctly surrealistic dream of an orchestra of nature to honour the divine new Caesar, Augustus. The latent parallelism with people seems to be apparent: the princeps as peace-bringer had managed to win over to peaceful conditions not only all people in his Empire but also and even its animal world. Here birds competed with people in expressing their salutation to the universal saviour god, the new Orpheus with his flying apostle. The exaggeration of the whole scene, with licence poétique, corresponds fully to the flattery deserved and probably expected by the ruler of the Roman world and his circle ${ }^{12}$. It would be tedious to look here for genuine religious feeling, when the imagination of a real court poet was at work. Court erudition and art may substitute their inspirations for realities. The Samian-Alexandrian astronomer Konon and Kallimachos who respectively recognized and poetically celebrated Berenike's hair as ascended into the sky may be seen as true intellectual forefathers of Krinagoras.

One will recognize this connection even better studying another jewel of Krinagoras' poetry where the motif of the ascension to heaven is applied to Augustus' favourite she-goat ${ }^{13}$. As already noted, the Mytilenean poet had closely followed and studied the conditions of Augustus' life on travel. Thus he knew probably firsthand that the princeps was always followed on his ways outside Rome by his dear she-goat, the tasty milk of which was his irreplaceable food. Augustus' weakness for that excellent animal nurse was such that he was never willing to do without her company. So far we have an unexpected bucolic piece to characterize Augustus' private habits. However, the poet dares to go further. He notes in the last two verses of the poem that the prospects of the sweet quadruped are great. The goat remarks here in the first person: «Some day I think I shall even reach the stars, for he to whom I gave suck from my breast is by no means inferior to the Aegiochos» (transl. W.R. Paton-modified in the Internet Attalus edition). Again with a superb Hellenistic talent for allusion, it is not the poet but the goat which indicates the status of her master: he is not less powerful than the traditional Aegis-bearer, literally the bearer of the goatskin attribute, that is Zeus ${ }^{14}$. The god mastering the world is paralleled with the god master of the Roman world through the example and the eyes of a she-goat. An idyllic scene (in both the original and the metaphorical sense of the expression) depicts Augustus' divine power. The princeps can no doubt reach the heaven, followed again by his faithful animal. One is tempted to comment: an apotheosis of and on four legs.

The fascinating simplicity of these images is not to be underestimated. They constitute a most effective flattery of Augustus who is presented and confirmed indirectly but forcefully as god. The praise of the emperor in this way is not offensive, but it remains overwhelming. It is flattery in its most ingenious form. One may recall at this point that in another field of letters, in rhetoric, the unknown author of the imperial (perhaps $1^{\text {st }}$

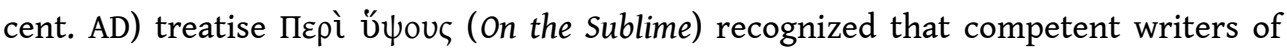
rhetorical works could now, under the political conditions of the Empire, manage to be

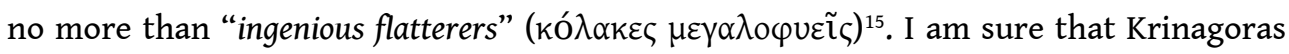
would tacitly consent. His elaborate images resourcefully served the new imperial god and his cult but the tradition of flattery was obvious all the same. Greek intellectuals knew right from the beginning of the Principate what they had to do but also what they really had in front of them with the dawn of the new imperial gods. Nice words and flattery were expected from them, and they had to be properly offered. The zeal could 
not be avoided but also not misunderstood, exactly against the Hellenistic background of ruler-cult.

\section{V}

20

, it is much less surprising to meet the rejection of the practice of imperial cult in Maecenas' speech to Augustus as conceived by Cassius Dio in the Severan age ${ }^{16}$. The internal distance and the reserves of Greek intellectuals were certainly much older, probably as old as the tradition and the methods of the ruler-cult itself. Then the weighty new factor in Severan times seems to be not so much the belated open realization of the basic religious emptiness of the cult as an exercise in flattery but the sober estimate of the costs involved to cover the multiple needs of the imperial cult in all its forms. It is noteworthy in this respect that Cassius Dio presents Maecenas' argument against such a background, emphasizing the need to spare important resources of the Empire wrongly invested in critical times. It is with such a reasoning that even the erection of temples for the emperor is discouraged from. In DioMaecenas' words: «For it is futile to spend great sums of money on such activities,

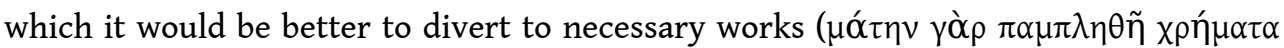

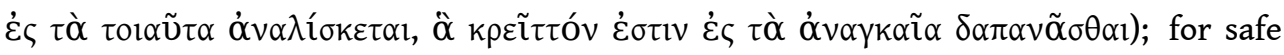
wealth is created not so much by copious income as through restricted expenditure».

the realiously aggravated circumstances of the Empire had decisively contributed to its presentation in public. However, it remains also noteworthy that Dio dared present these views more comfortably as stemming from Augustus' main counsellor, and thus more or less as an 'objective estimate' of a time-respected imperial administrator. Even now the negation of a whole and essential state mechanism cannot have been a simple undertaking.

\section{VI}

The other side of the coin, even in Greek intellectual circles, may be exemplified by Lucian's testimony on the imperial cult. The Hellenized Samosatan, who worked in the imperial service (after his own report, he had a responsible position in the office of the praefectus Aegypti $)^{17}$ in Antonine times has no problem in understanding and accepting the imperial cult as a counter-offer, a sort of remuneration, of the imperial subjects to their benefactor the emperor ${ }^{18}$. Thus he moulds the imperial cult into the other traditional strain of Greek thought, namely the heroization/deification of benefactors of a human community. The crucial difference is, of course, that this euergetic merit should correspond to real facts and not be testified simply through a formal decision of whichever voting - and quite possibly manageable - body. It was important here to tell flattery from real conviction on the ruler's merit, as experience had also shown.

The simultaneous rejection of voting as a source of legitimation for the ruler-cult establishes again a continuity in the Greek intellectuals' stance towards the imperial cult. For it is first no accident that Dio-Maecenas' admonitions to Augustus/Augusti includes also the fundamental principle that «many humans have been elevated to divine status due to their moral worth but no one has ever attained this through a 


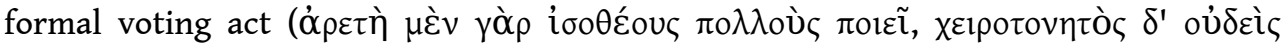

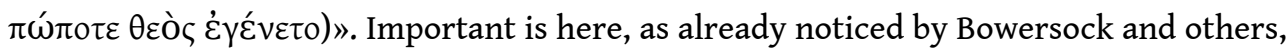
that the kernel of this idea was not new in Greek literature of the imperial period. We find it also, again in a comfortably marginal way, in Plutarch's biography of Romulus ${ }^{19}$. There it is stressed that Romulus-Quirinus' divine status was imposed by the sheer truth and reason, that is by the moral state of things itself, and not by any decree of $a$ city (ov̉ vó $\mu \omega$ ró $\operatorname{c} \varepsilon \omega \varsigma$ ).

\section{VII}

24 An equally practical stance to the imperial cult as in Lucian appears also in Aelius Aristides, reflecting again the ideas of people directly or indirectly connected with Roman administration. The moody orator once refers in the same context of his Roman Oration $^{20}$ to elements of both the traditional gods' and the emperors' cult. His model imperial official is there presented as praying first to the (traditional) gods for the

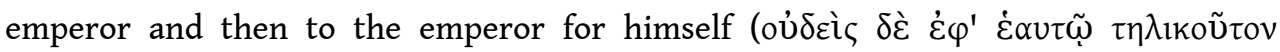

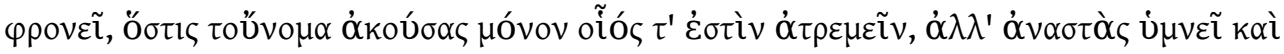

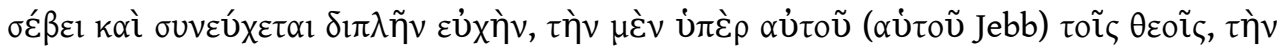

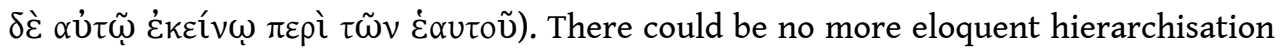
of prayers to higher powers, with the emperors understood as unquestionable euergetic sources of potential welfare for even the distinguished humans of his time. It would have made no sense in Aristides' (and probably most of his contemporaries') view to dispute such a basic reality. The possibly problematic application of such a system under unworthy emperors did not seem to apply to the data of that period, and it did not deserve mention in that genre of speech.

An equally dexterous treatment of the subject of imperial cult appears also in Aristides' speech on the dedication of a temple of the provincial cult of Asia at Kyzikos ${ }^{21}$. As Bowersock has correctly analysed its evidence ${ }^{22}$, the orator does not refer to the essence of Hadrian's cult practiced there, although he alludes to its dedicatory inscription, which should have been $\theta \varepsilon \tilde{\omega}$ A A $\delta \rho \alpha v \tilde{\omega}^{23}$. According to the same work of Aristides, the dedication of the temple should express the provincial gratitude to the

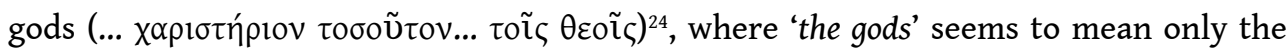
traditional deities.

In other passages of his later Letter to the Emperors [Marcus Aurelius and Commodus] about Smyrna, written after the earthquake of $178 \mathrm{AD}^{25}$, however, Aristides distinguished even more clearly between gods and emperors as men, without questioning at the same time in any way the idea of the imperial cult as an institution of the Empire.

\section{Conclusions}

We may conclude that the attitude of Greek intellectuals to the Roman imperial cult followed differentiated principles, both in its own evolution and in the framework of Greek and Hellenistic traditions of divine rulers, and those principles long predate the Severan age. What appears then as an 'eruption of truth' after the especially negative examples of Commodus and Elagabalus is rather a natural response to the financial 
straits of the Empire in the $3^{\text {rd }}$ cent. $\mathrm{AD}$, which let already existing reservations and discreet opposition to the imperial cult as a really religious entity more daringly appear. The ruler-cult of the Roman emperors was on the one hand securely based on its Hellenistic foundation and its adulatory methods, on the other hand it had also to correspond to the rules of real euergetism that shaped its roots. The issue of its moral content could never too easily be silenced, especially against this latter background and in Greek intellectual context. Essential state-rituals were securely enthroned, as a sort of tacit contract with imperial power ${ }^{26}$ (and even added to the appealing instruments of social show off, as forcefully attested by Epictetus ${ }^{27}$, but moral thinking on religious matters was in no phase completely dethroned either. The tradition was twofold, expressed both as conformity and as dissent of various degrees ${ }^{28}$.

\section{BIBLIOGRAPHY}

BOWERSOCK 1973: G.W. Bowersock, «Greek Intellectuals and the Imperial Cult in the Second Century A.D.», in: Le culte des souverains dans l'Empire romain, Fondation Hardt. Entretiens sur l'Antiquité Classique, tome XIX (Entretiens préparés et présidés par W. den Boer), VandoeuvresGenève 1973, 179-212.

Clauss 1999: M. Clauss, Kaiser und Gott. Herrscherkult im römischen Reich, Stuttgart/Leipzig 1999.

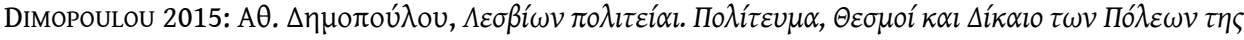
$\Lambda \varepsilon ́ \sigma \beta o v$, Athens 2015.

GRADEL 2002: It. Gradel, Emperor Worship and Roman Religion, Oxford 2002.

HABICHT 1985: Chr. Habicht, Pausanias und seine "Beschreibung Griechenlands", Muenchen 1985.

LABARRE 1996: G. Labarre, Les cités de Lesbos aux époques hellénistique et impériale, Lyon 1996.

MASON 1974: H. Mason, Greek Terms for Roman Institutions. A Lexicon and Analysis, Toronto

(American Studies in Papyrology, 13) 1974.

MCINTYRE 2019: G. McIntyre, Imperial Cult (Brill Research Perspectives/Ancient History), Leiden 2019.

MogGI, Osanna 2003: M. Moggi, M. Osanna (eds), Pausania, Guida della Grecia, Libro VIII : L'Arcadia, Milano 2003.

PRICE 1984: S. Price, Rituals and Power. The Roman Imperial Cult in Asia Minor, Cambridge 1984.

\section{NOTES}

1. BOWERSOCK 1973, 206.

2. Ib. 205

3. PRICE 1984, 116.

4. Cf. НАBICHT 1985, 21. 


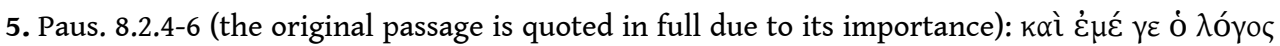

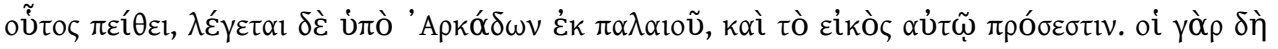

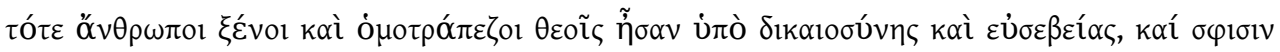

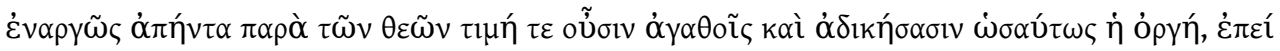

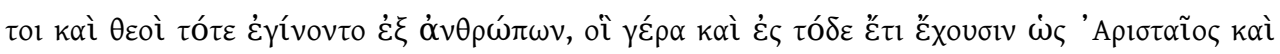

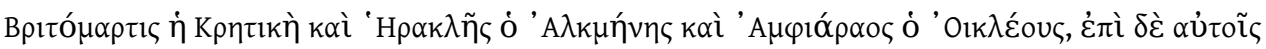

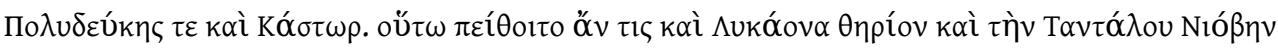

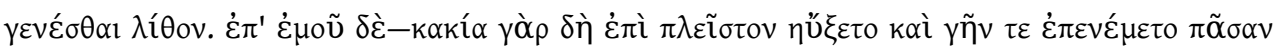

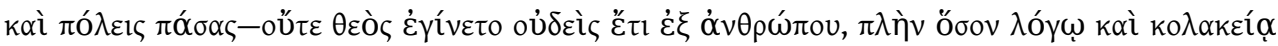

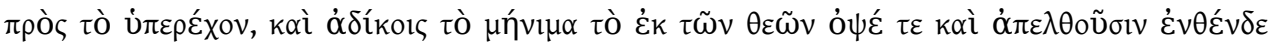

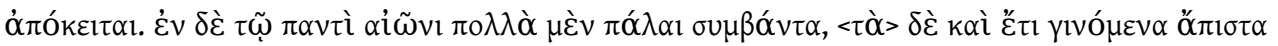

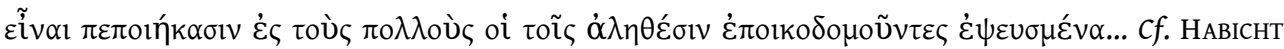
1985, 154 (Pausanias' remarks referred in general to the cult of Hellenistic kings and Roman emperors); MOGGI, OSANNA 2003, 298 (also preferring to recognize here an overall allusion to the ancient cult of living rulers: '...potenti, imperatori compresi, quando erano ancora in vita').

6. Paus. 6. 3. 16.

7. On this sense of $\theta \varepsilon \rho \alpha \pi \varepsilon v ́ \omega$ already in classical Greek and then in later authors see LSJ s.v. (esp. Plut. Per. 34. 2; Diog. L. 9. 63).

8. Plut. Mor. 56 D-F.

9. BOWERSOCK 1973, 191.

10. On Krinagoras' Mytilenaean and temporal/social background cf. esp. LABARRE 1996, 99, 105, 145. Dimopoulou 2015, 519f. Krinagoras' poems have attracted the interest of another big Greek poet in our times, Odysseas Elytis (Nobel Prize 1979), who undertook to translate them into modern Greek (with some philological-historical comments) and adorn them with five paintings by himself (Athens: Hypsilon 1987).

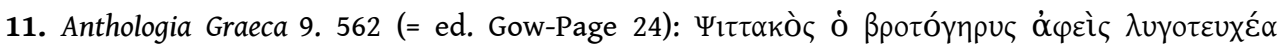

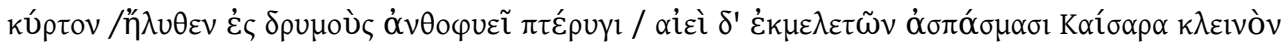

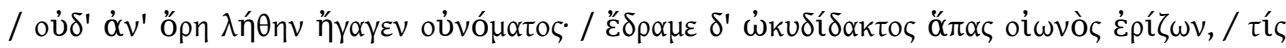

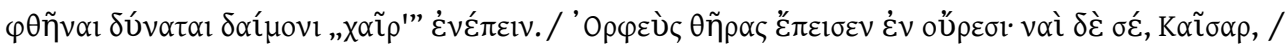

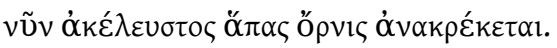

12. As Massimo Nafissi suggested to me during the colloquium, even a fine dose of satirical irony may be discerned in the underlying antithesis between the 'parrot with human voice'

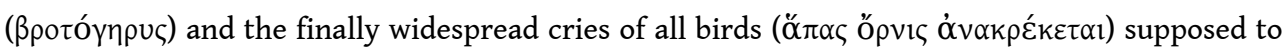
repeat the salutation to Caesar Augustus.

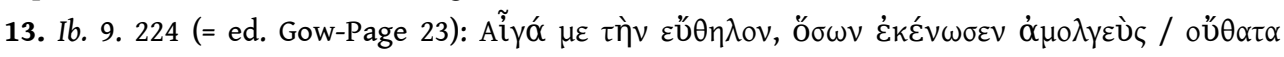

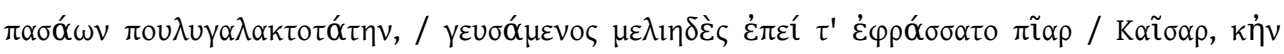

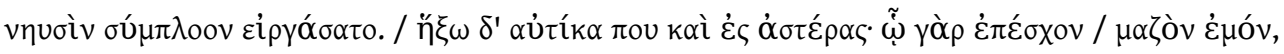

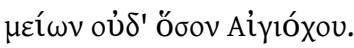

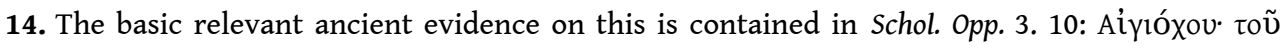

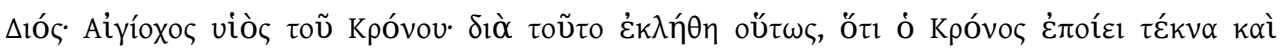

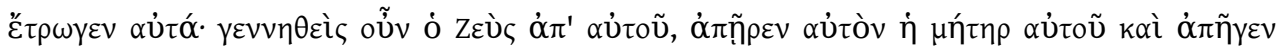

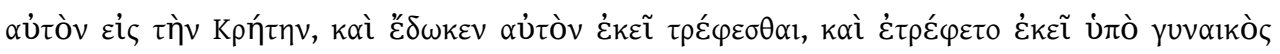

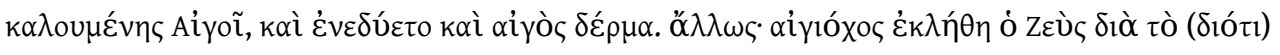

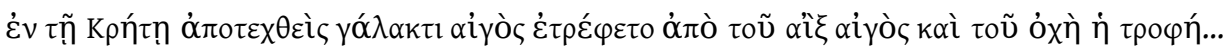

15. Ps. Longinus 44 . The unknown author emphasizes the lost possibilities of classical democracy

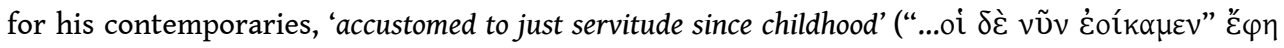

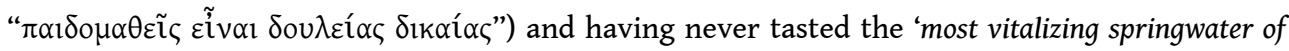

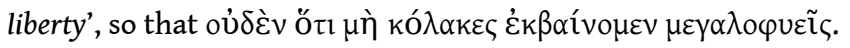


16. Cassius Dio 52. 35-6. The whole relevant passage of this sober argument of Dio/Maecenas: ...

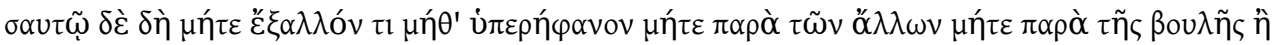

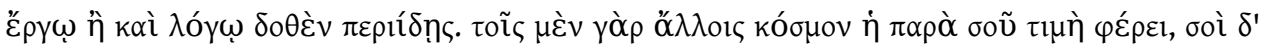
$\alpha$

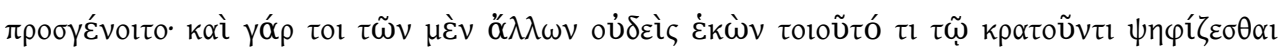

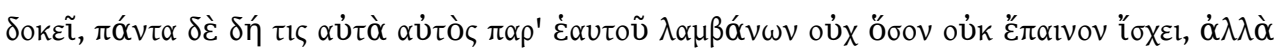

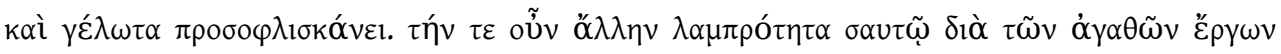

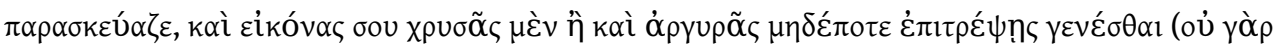

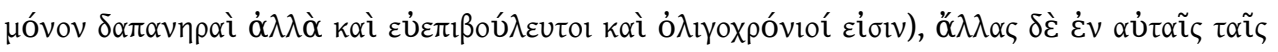

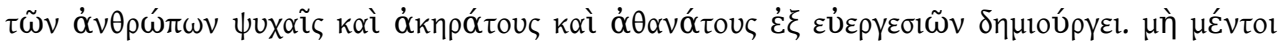

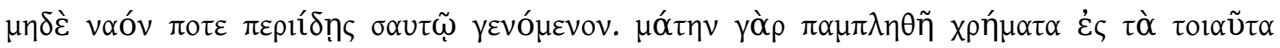

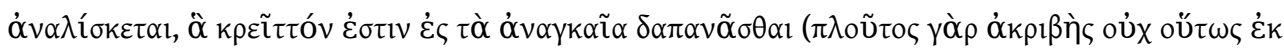

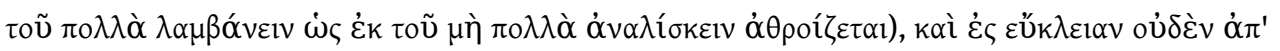

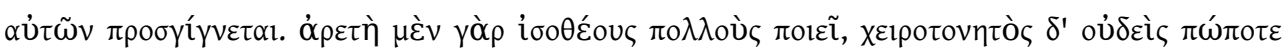

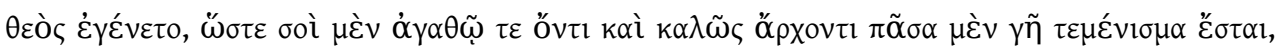

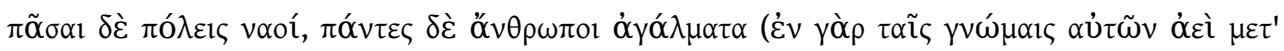

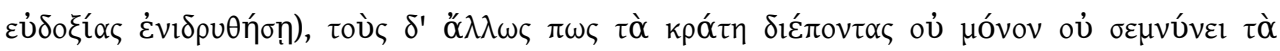

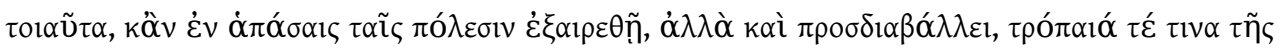

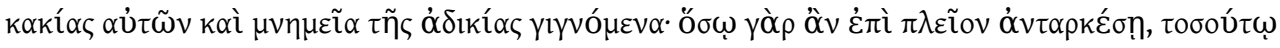

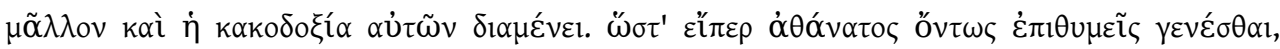

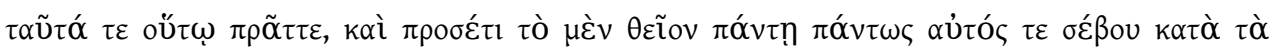

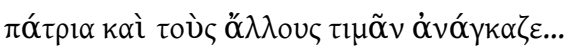

17. Luc. Apol. 12. Mason 1974, 114 identifies his position with that of the archistator praefecti Aegypti.

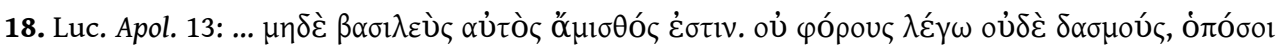

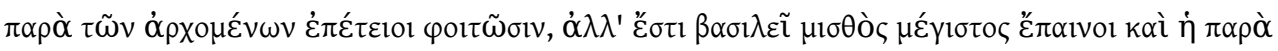

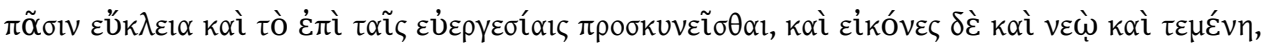

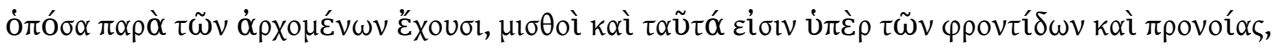

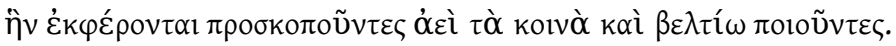

19. Plut. Rom. 28. The whole passage explains nicely the gradual elevation of human souls to

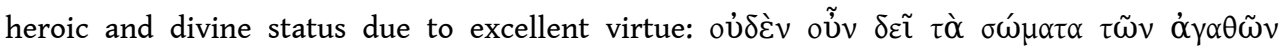

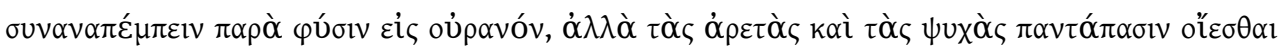

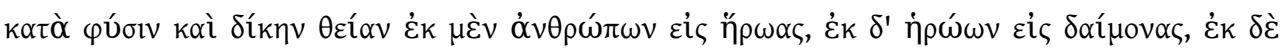

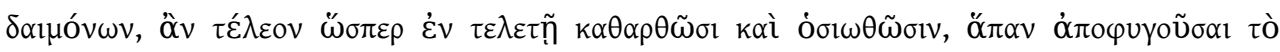

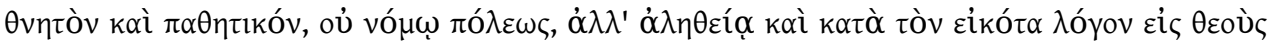

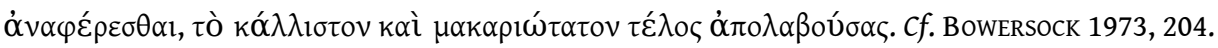

20. Ael. Arist. 26 Keil, 32.

21. Id. 27 Keil.

22. BOWERSOCK 1973, 195-7.

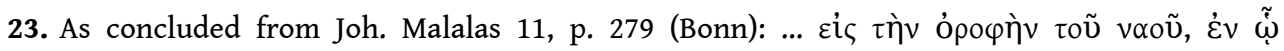

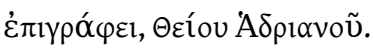

24. Ael. Arist. 27 Keil, 22.

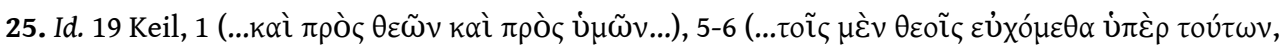

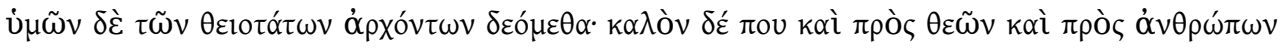

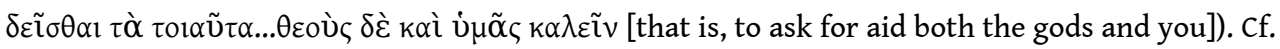
BOWERSOCK 1973, $199 f$.

26. Cf. esp. the conclusions of the comprehensive monograph by GRADEL 2002, 369-71. CLAUSS 1999 had preferred, on the other hand, as a result (cf. esp. 469-99) of his detailed study, to emphasize the real acceptance of the emperor's divinity by all subjects against the context of the relation 
between power and divine status in the Roman imperial world. Cf. now also the useful, updated survey of various aspects of Roman imperial cult by MCINTYRE 2019.

27. Diatr. I.19.26-9.

28. Warm thanks are due to John K. Davies who kindly revised my English text and suggested improvements.

\section{ABSTRACTS}

The stance of Greek intellectuals towards the idea and the practice of Roman emperor cult has been often examined, with the main result that the complacent, conformist attitude of these subjects of the Empire has been ascertained (thus in a still basic study by G.W. Bowersock, 1973). A new scrutiny of the available evidence, however, spots also serious reserves in that circle towards the real content of emperor worship at least since the Antonine age, while outright and conscious flattery as driving force and quintessence of the imperial cult appears even earlier. After the proper analysis, cultic acceptance of a real benefactor-emperor, refined flattery or careful, direct or indirect, rejection appear as the three poles around which the attitudes of Greek intellectuals towards the imperial cult circled. Essentially, all three variant stances continued threads of reaction to the practice of ruler-cult beginning already in Hellenistic times, thus pointing to an underlying continuity between the ideological picture of the ruler in this period and the Roman Empire.

La posizione degli intellettuali greci nei confronti dell'idea e della pratica del culto dell'imperatore romano è stata spesso oggetto di indagine, permettendo di accertare l'attitudine compiacente e conformista di questi sudditi dell'Impero (come emerge da uno studio ancora fondamentale di G.W. Bowersock, 1973). Un nuovo esame delle testimonianze disponibili, tuttavia, consente di mettere in evidenza anche le pesanti riserve che questi gruppi nutrivano verso la reale concretezza del culto imperiale almeno a partire dall'epoca degli Antonini, mentre la vera e consapevole adulazione come forza motrice e quintessenza del culto imperiale appare già in precedenza. A un'analisi più approfondita, l'accettazione del culto di un imperatore evergete, l'adulazione elegante o il rifiuto attento, diretto o indiretto, appaiono come i tre poli attorno ai quali ruotano gli atteggiamenti degli intellettuali greci nei confronti del culto imperiale. Questi tre atteggiamenti affondano le loro radici anche nelle differenti reazioni alla pratica del culto del sovrano già in epoca ellenistica, indicando così una continuità di fondo tra il quadro ideologico del sovrano in questo periodo e quello che caratterizza l'Impero romano.

\section{INDEX}

Keywords: Ruler-Cult (Hellenistic, Roman imperial), Greek Intellectuals of the Roman imperial period, Pausanias, Krinagoras, Plutarch, Cassius Dio, Lucian, Aelius Aristides

Parole chiave: culto del sovrano in età ellenistico-romana, intellettuali greci di epoca imperiale, Pausania, Krinagora, Plutarco, Cassio Dione, Luciano, Elio Aristide 


\section{AUTHOR}

\section{KOSTAS BURASELIS}

Professor emeritus of Ancient History, National and Kapodistrian University of Athens

Kyprianu 2

GR-16341 Iliupoli-Athens

kburasel(at)arch.uoa.gr 